\title{
Wood-based bioenergy in western Montana: the importance of understanding path dependence and local context for resilience
}

\author{
Tyler A. Beeton ${ }^{1}$ and Kathleen A. Galvin ${ }^{2}$
}

\begin{abstract}
The use of biomass for wood-based bioenergy (WBB) has been argued as a mechanism to mitigate the impacts of climate change, reduce vulnerability to disturbance events such as fires, and to enhance rural socioeconomic development. Yet, WBB development is characterized by a multitude of feedstock sources, bioenergy pathways, scales, and end uses, the feasibility of which is contingent upon place-based and context-specific social and environmental factors. We present an exploratory case study that draws on key informant interviews among a cohort of diverse stakeholders in rural western Montana forest communities, which was informed by a social-ecological systems framework and resilience thinking from a social science lens. The purpose of this paper is the following: (a) to document the ways in which key informants define the opportunities and constraints associated with WBB in local contexts; and (b) to understand how, and under what contexts, WBB can contribute to forest and community resilience under change. Interviews were analyzed using a modified grounded theory approach, and supplemented by document analysis. Results illustrate the ways in which historical contingencies (i.e., path dependence), individual and group values, and social context can affect the capacity to implement WBB projects. Results also help identify multiple perspectives and trade-offs, which can provide a step toward identifying the most desirable and plausible options for WBB development. As such, these lessons can be used as a starting point to help determine WBB development pathways that contribute to the social and ecological resilience of local places and people under change.
\end{abstract}

Key Words: bioenergy; path dependence; renewable energy; resilience; Rocky Mountains; social-ecological systems

\section{INTRODUCTION}

Forests in the Northern Rockies are undergoing myriad ecological and social changes, which has altered the structure and function of ecosystems, and contributed to loss of livelihoods. For instance, climate change impacts including increased temperatures, altered precipitation regimes, and an increase in the incidence of drought has increased the frequency, extent, and severity of pest and pathogen disturbances and catastrophic wildfire (Allen et al. 2010, Bentz et al. 2010, Dennison et al. 2014). Many of these ecological changes have been exacerbated by social factors, such as fire suppression and past logging operations, which have altered forest stand structure and composition and increased the vulnerability of forest systems to disturbance (Haugo et al. 2010, Lydersen et al. 2013).

The combination of these social and ecological changes has resulted in vast amounts of dead and downed trees and dense, small-diameter stands that are in need of restoration to restore forest health and resiliency (Eckhoff and Mackes 2010). However, the international restructuring of forest products markets, and divestments of industrial timberlands to Timber Investment Management Organizations (TIMOs) and Real Estate Investment Trusts (REITs), among other drivers, has crippled forest products industries and the capacity to manage forests in many places across the western U.S. (Bliss et al. 2010, Toppinen et al. 2010). Further, the low value of forest residues, coupled with the high costs to remove the material limits treatments without government subsidies and/or value added products to offset costs (Donoghue and Sturtevant 2008).

The use of biomass (e.g., forest residues from commercial operations and thinning treatments or mill wastes) for wood- based bioenergy (WBB) has been argued as a valued added product that would serve to support climate change mitigation and adaptation efforts by reducing fossil fuel dependence, reducing vulnerability to disturbance events, and enhancing rural economic and community development (Richter et al. 2009, Eckhoff and Mackes 2010, Openshaw 2010, Dale et al. 2014). As interest in, and the development of, WBB continues to grow, forests will be used, and stakeholders will be affected, in a variety of ways. This is due in part to the multitude of feedstock sources, bioenergy pathways, scales, and end uses for WBB. Each of these has unique options and constraints that are context- and placedependent (Hitchner et al. 2014). Furthermore, the feasibility of new energy development does not occur in a vacuum, but is embedded in historical and contemporary socio-cultural, political, economic, and environmental factors (e.g., Polagye et al. 2007, Hoekman 2009, West et al. 2010, Jones et al. 2013, Strauss and Reeser 2013, Caputo et al. 2016). These factors, in turn, can enable or constrain WBB development. Therefore, the feasibility of WBB is the product of social and ecological contexts, thus necessitating an urgent need for a systems view to better understand local perspectives of WBB (e.g., Hodbod and Adger 2014).

This exploratory case study draws on semistructured interviews with a sample of key informants representing diverse forest stakeholder groups in western Montana. The study is informed by a social-ecological systems (SES) framework and resilience thinking. The objectives of this study are twofold: (1) to document the ways in which key informants define the opportunities and constraints associated with WBB in local contexts; and (b) understand how, and under what contexts, WBB might contribute to forest and community resilience under change.

\footnotetext{
${ }^{1}$ Department of Anthropology \& North Central Climate Science Center, Natural Resource Ecology Laboratory, Colorado State University,

${ }^{2}$ Department of Anthropology \& Natural Resource Ecology Laboratory, Colorado State University
} 
Conceptual framework: a systems approach and resilience thinking to address wood-based bioenergy and forest management We utilized an SES perspective and resilience thinking from a social science lens to frame this study. The SES approach emphasizes the interconnectedness of social and ecological systems, in that humans depend on ecosystems and the services they provide, which in turn are affected in part by management decisions (Westley et al. 2002, Berkes et al. 2003). The resilience concept has been used extensively to better understand and characterize dynamics that operate between SESs (Folke 2006). Resilience can be defined as "the capacity of a system to absorb disturbance and reorganize while undergoing change so as to still retain essentially the same function, structure, identity, and feedbacks" (Walker et al. 2004). Resilience thinking links the concepts of adaptation (and adaptive capacity) and transformation to resilience (Folke et al. 2010). In doing so, resilience thinking helps to characterize nonlinear dynamics, thresholds, uncertainty and surprise, and the interaction of slow and fast variables across system components and spatio-temporal scales (Gunderson and Holling 2002, Folke 2006).

Historically, ecological, institutional, and economic outcomebased approaches have dominated the resilience literature. However, recent critiques of resilience thinking from the social sciences argue for a broadening of the scope of resilience analysis to address history, socio-cultural and political context, human agency, values and discourses, and power (Cote and Nightingale 2011, Armitage et al. 2012, Brown 2014). We highlight some of these below.

Particularly germane to this paper, resilience-thinking considers the role of historical legacies in creating path dependent trajectories of change. Path dependence was originally coined in the institutional economics literature (North 1990), and has since been applied to understanding temporal dynamics and feedbacks in SESs. Path dependence is a term used to describe the ways that decisions made in the past can affect resilience and adaptive capacity of the current SES, and in doing so can limit the options that are available for change now and into the future (Nelson et al. 2007). There is a potential for "lock-in" whereby institutional arrangements can effectively undermine the capacity to respond to change, while "path creation" is considered an important component of "delocking" negative path trajectories and maintaining the flexibility to respond to change (Scott 2013).

There are several examples of path dependence in forest management and energy systems contexts. For instance, legislation passed in the late 1960s and early 1970s, such as the National Environmental Policy Act (NEPA) of 1969 and the Endangered Species Act (ESA) of 1973, provided a mechanism by which public groups could challenge forest management practices in court. These Acts led to large-scale reduction in timber harvesting in forests on U.S. public lands, and has shifted the management objectives and major land uses on these forests (Trosper 2003, Donoghue and Sturtevant 2008, Beier et al. 2009). In a similar vein, the global restructuring of timber markets and economies from Europe and North American markets to Latin America, and consequently the divestment of many corporate industrial private landholdings to TIMOs and REITs, has led to land fragmentation and significant changes in land use and land tenure (Bliss et al. 2010, Toppinen et al. 2010). As a result, mills have closed, smallholder and regional markets have been affected, and the capacity to manage forests has decreased in many places. Finally, path dependencies fuel current energy systems (Unruh 2000, Lovio et al. 2011). As described by Unruh, "industrial economies have been locked into fossil fuel-based energy systems through a process of technological and institutional co-evolution driven by path-dependent increasing returns to scale" (Unruh 2000:817). The barriers to "delock" this trajectory and create pathways toward renewable energy include social, political, and economical factors such as vested interests, market barriers, and the difficulty in transforming (e.g., resistance to change) traditional modes of electricity generation (Sovacool 2009a,b).

Forest management is in part determined by economics and policy, and WBB development could provide a stimulus for forest management investment. However, WBB systems are ultimately dependent on a robust infrastructure and market for forest products, in addition to an enabling environment for nonrenewable energy development. Therefore, these path dependencies may create challenges to developing and implementing emerging WBB technologies in local places.

Resilience thinking from a social science lens also acknowledges that SESs can exhibit multiple system states as a function of diverse stakeholder objectives and values (Nelson et al. 2007). A forest ecosystem can support a variety of provisioning, regulating, supporting, and cultural services, and in a variety of combinations (Díaz et al. 2015). One community or group, whose livelihood depends on timber extraction, may desire a state that ensures the delivery of fuel and fiber (i.e., provisioning service) at the expense of, or above, protecting supporting services (e.g., biodiversity conservation). Another community or group may desire the opposite system state, which can create conflict among forest users.

Still, there is a lack of research that addresses human values, agency, and aspirations in the resilience literature, or the normative nature of resilience (Crane 2010, Cote and Nightingale 2011, Armitage et al. 2012, Brown 2014). Specifically, there is a lack of research on how values shape the historical and future trajectories of change, and whether a given ecological or social state is desirable and/or possible. This is particularly critical in areas where diverse stakeholder groups hold very different values and aspirations for development. In this context, resilience can be considered a socially and culturally defined experience that is characterized in part by the valuation of landscapes, natural resources, and individual practices (Marshke and Berkes 2006, Crane 2010). For instance, Marshke and Berkes (2006) documented local perspectives of resilience, through the lens of well-being and sustainability, among fishing communities in Cambodia, finding that communities had a solid understanding of the near-term and plausible management targets that needed to be considered. These management targets reflected community values, which in turn reflected the particular social and environmental contexts in which the communities were embedded. Therefore, it is important to characterize diverse values systems in local contexts on their own accord, but also as a means to better understand the social, cultural, and political factors that characterize deeper drivers of change (Cote and Nightingale 2011). These values are shaped by the social, political, and cultural milieu of local places, which ultimately determine 
Fig. 1. Map of case study extent. Top left inset illustrates the location of the state of Montana in North America; top right inset depicts location of study extent with respect to the administrative boundaries of Montana. Watershed boundaries and the distribution of public lands (USDA Forest Service [dark green], Montana State Trust lands [light green]) are illustrated. The location of interviews and local towns within the three watersheds are also depicted. Source: Basemap layers provided by Environmental Systems Research Institute (ESRI), Montana State Trust Lands (http://svc.mt.gov/msl/mtcadastral/).

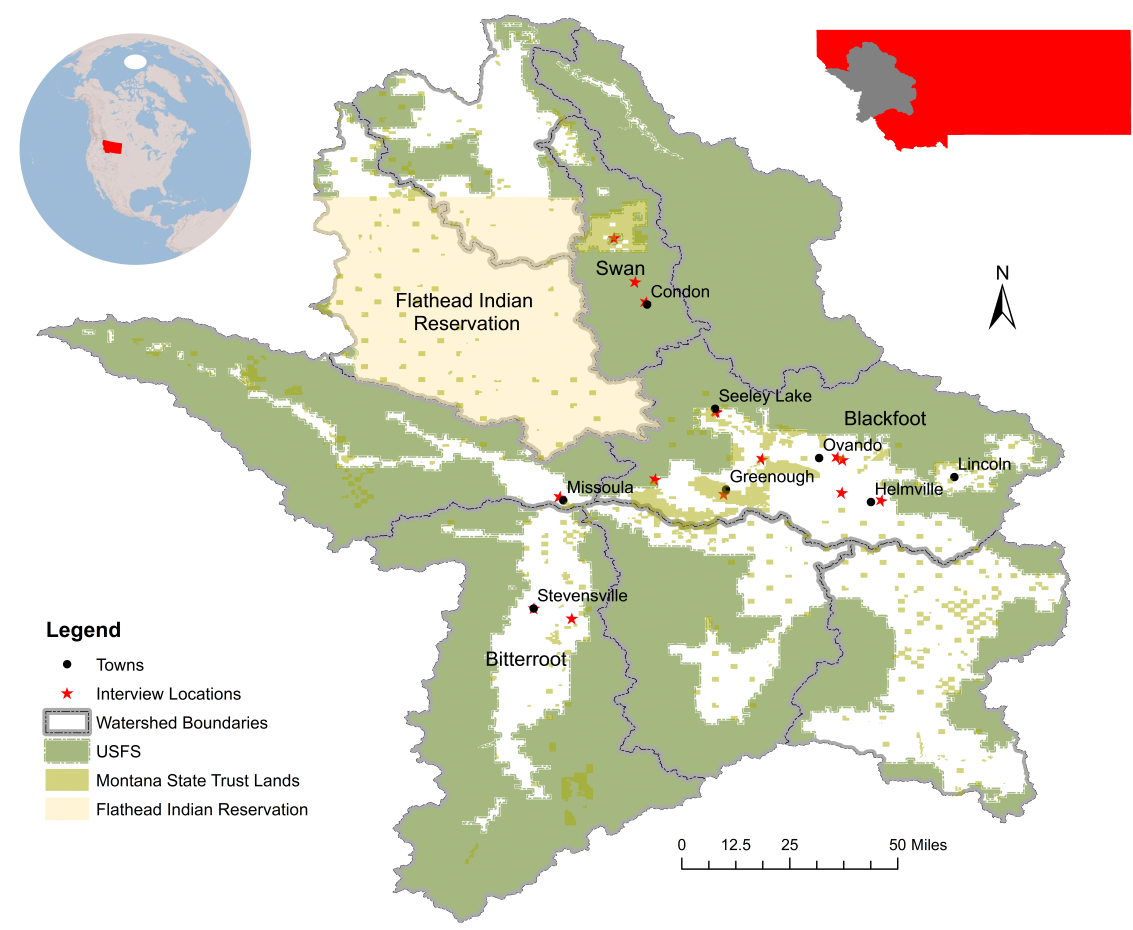

how humans interact with their environment, what states and conditions are considered desirable and/or plausible, the strategies that are considered to deal with change, and the capacity to do so (Smit and Wandel 2006, Crane 2010).

In sum, a SES resilience perspective from a social science lens allows for an understanding of linkages and feedbacks in system components within and between scales. Resilience thinking offers a framework to conceptualize how past actions limit options now and into the future, and the ways in which values situated within socio-cultural, political, economic, and environmental contexts combine to affect the options that are considered to deal with change. A resilience perspective helps to illustrate multiple, and at times, conflicting values and objectives, which can help to determine those most appropriate and practical strategies to build resilience under change. We argue that understanding how historical, socio-cultural, and political factors at multiple scales play out in local contexts, and documenting local perspectives of the capacities and barriers to adopt WBB pathways in these contexts is essential to determine for what, and for whom, resilience is sought (Lebel et al. 2006).

\section{METHODS}

This exploratory case study was informed by semistructured interviews in western Montana with a sample of key informants involved in forest management. A modified grounded theory (GT) approach was used to analyze interview transcripts, and was supplemented with document analysis.

\section{Case study background}

This case study was carried out among key informants who reside in rural forest communities across three watersheds (Swan, Bitteroot, and Blackfoot) in western Montana (Fig. 1). These communities are relatively small (e.g., Condon, pop. 343; Ovando, pop. 71; Stevensville, pop. 1868). Forest habitat types in this area of western Montana west of the Continental Divide are diverse, and characterized according to fire zones, temperature and moisture gradients ranging from hot-dry sites to cold-moist sites, and/or elevational thresholds (Fischer and Bradley 1987, Mehl et al. 2012). The variety of tree species in these landscapes include ponderosa pine (Pinus ponderosa), Douglas fir (Pseudotsuga menziesii), lodgepole pine (Pinus contorta), western larch (Larix occidentalis), Engelmann spruce (Picea engelmannii), subalpine fir (Abies lasiocarpa), whitebark pine (Pinus albicaulis), western red cedar (Thuja plicata), western hemlock (Tsuga heterophylla), among others (Mehl et al. 2012). Notably, there is an increasing dominance of Douglas fir on some sites previously occupied by ponderosa pine. Also, whitebark pine communities are in decline in some areas as a function of past and more recent pest and pathogen disturbances, such as the mountain pine beetle (Dendroctonus ponderosae), and successional replacement by 
subalpine fir (Keane and Arno 1993, DNRC 2014). The recent mountain pine beetle epidemic has resulted in tree mortality on $\sim 2.5$ million hectares of forest in Montana of lodgepole pine, ponderosa pine, and whitepark pine (DNRC 2014).

This area of western Montana is situated within the southwestern portion of the Crown of the Continent Ecosystem (CCE), and supports critical habitat for a number of fish and wildlife species (Prato and Fagre 2007). For instance, in the Flathead National Forest (Swan watershed; Fig. 1), $1240 \mathrm{~km}$ of streams have been designated critical bull trout (Salvelinus confluentus) habitat, 90\% of the forest is considered high-to-moderate value habitat for the threatened grizzly bear (Ursos arctos), the northern reaches of the forest house the highest inland density of grizzlies, and the forest is home to the largest population of wolverines (Gulo gulo) in the contiguous U.S. (Weaver 2014).

Historically, the timber industry drove local economies. However, destructive logging and increasing concerns of environmental degradation among local conservation and environmental groups has created conflict among diverse users concerning natural resource management (Cestero and Belsky 2003). Current land uses include timber production industries to some degree, grazing, and forage crops, however the region is witnessing an increase in, and the support for, recreation and tourism industries. For instance, the Montana Department of Fish and Wildlife estimated that in 2008 anglers spent US\$240 million alone on personal purchases in the state (Baginski and Biermann 2010), and total spending from nonresidents equaled US\$3.9 billion in 2014 (Montana Office of Tourism 2015). Land ownership consists of public lands (United States Department of Agriculture [USDA] Forest Service [USFS], Montana Department of Natural Resources and Conservation (DNRC), Bureau of Land Management [BLM]), private landowners, and corporate private land holdings, such as Plum Creek Timber Company.

Land prices have risen significantly over the last two decades in this region, and were the impetus for Plum Creek to divest the majority of their landholdings from corporate timberlands to real estate (Belsky 2015). Since then, most of the remaining Plum Creek land has been sold off to a variety of entities, the majority of which went to the USFS and DNRC. The USFS acquired these lands through a purchase by The Nature Conservancy (TNC) with a fiber agreement mandating timber sales in an effort to support the forest products industry (Parker 2014, Belsky 2015).

Several communities and organizations are utilizing biomass for WBB in the region. For instance, the Darby school district, with funding from the National Fire Plan, opened the first "Fuels for Schools" program in 2003. In 2010, the biomass boiler saved the school US\$200,000, and has contributed to local job creation (Westover 2011). Since the success of the Darby school district, nine other communities across western Montana have installed biomass boilers in primary and secondary schools from 2003 to 2009. The University of Montana-Western campus in Dillon also installed a biomass boiler in 2007 (Farr 2011). Further, in $2013 \mathrm{~F}$. H. Stoltze Land and Lumber Co. opened a US\$22 million combined heat and power (CHP) plant (Peterson 2013). The plant uses wood waste from Stolze's and other mills to provide heat to the mill and to dry wood. Additionally, the CHP plant also will produce up to 2.5 megawatts (MW) of power to Flathead Electric Co-op for the next 20 years, which will provide electricity for up to 2500 homes (Murray 2013). Wood wastes are primarily generated from contracts on private and state lands, even though federal public lands surround the mill in Columbia Falls, Montana (Peterson 2013).

Therefore, this region of Montana is undergoing a host of changes. Although communities and organizations strive to maintain the social and cultural fabric of the region, multijurisdictional ownership, in addition to changes in land tenure and values creates problems in practice, particularly with regard to balancing agricultural production and timber extraction, with increasing revenues from recreation and tourism, and conservation concerns in this diverse landscape.

\section{Key informant interviews}

Semistructured interviews $(\mathrm{n}=17)$ were conducted with a sample of key informants who are involved in forest management, and who have considerable knowledge of the historical context, and the social and ecological factors that affect forest management and WBB in the area, through a combination of in-person and phone interviews. Public and private land managers, forest products industry professionals, such as mill workers, loggers, and biomass specialists, DNRC Service Foresters, a restoration specialist/forest ecologist, members of community conservation organizations who work directly with private land owners in the area on forest management and conservation issues (e.g., Blackfoot Challenge, Swan Ecosystem Center), and a representative from a local environmental nongovernmental organization (ENGO) were identified using a combination of purposive and snowball sampling (Table 1; Patton 2002, Bernard 2006). Extension specialists from the University of Montana provided entree into the communities and connected us with public and private land managers, and forest products professionals. Additionally, we contacted DNRC Service Foresters in the area who work closely with private land managers to identify additional interviewees. Finally, early in the interview phase some of the informants recommended contacts who could offer additional insight. For this exploratory analysis, our key informant sample was purposively small and consisted primarily of individuals who have lived in these forests, and were involved in forest management in the area for many years. This included second and third generation loggers, private ranchers and timberland owners, and forest managers with $20+$ years of experience working and living in these forests, for example.

Table 1. Number of key informants by stakeholder group in the study sample.

\begin{tabular}{lc}
\hline \hline Stakeholder group & $\begin{array}{c}\text { Number of key } \\
\text { informants }\end{array}$ \\
\hline Private land manager & 5 \\
Forest products professional & 4 \\
Community conservation organization & 2 \\
member & 2 \\
Public forest manager & 2 \\
DNRC ${ }^{\dagger}$ Service Forester & 1 \\
Restoration specialist & 1 \\
ENGO member & \\
\hline
\end{tabular}

${ }^{\dagger}$ Montana Department of Natural Resources and Conservation.

${ }^{\star}$ Environmental non-governmental organization. 
The sampling strategy helped to document the historical context and changes in forest social-ecological systems over time. We argue that the sample provides a set of key insights, multiple perspectives, and contradictions among informants that offers a starting point to identify the opportunities and constraints to forest management in general, and WBB specifically in this area. Further, as we discuss below, our results reflect many of the same issues identified in recent syntheses of public opinion of WBB (e.g., Becker et al. 2011, Hitchner et al. 2014), and our interview/document analysis of the proposed University of Montana biomass boiler provides additional context from members of the public not necessarily embedded in forest management issues. However, we acknowledge that this is not a representative sample of all of the individuals and groups who would have influence on, and who would need to be considered in, decisions regarding the siting, design, scale, implementation, etc. of WBB. Therefore, extending this interview protocol or a survey instrument based on the results that follow to other groups who are not embedded in forest management contexts, such as members of the broader public, would need to be considered in future studies for a more comprehensive understanding of the multiple and context-specific factors that enable or hinder WBB development.

Key informant interviews were audio-recorded and averaged one hour each in duration. Interview questions addressed local perspectives of forest ecological state and use, the social and ecological changes occurring on their landscapes, the factors that shape forest management on public and private land, local bioenergy development in the area, and the opportunities/barriers to WBB in the context of ensuring sustainable forests and communities (See Appendix 1 for interview protocol). Issues that were pertinent to this case study was to understand the historical context of forest management, the wood products industry and infrastructure, and WBB in the region; the multiple perspectives regarding forest management and WBB; and the ways in which informants situated WBB in the context of sustainability.

\section{Data analysis}

Semistructured interviews were audio-recorded and transcribed, and then analyzed using a modified grounded theory (GT) approach. GT was originally developed by Glaser and Strauss (1967), and is a set of systematic rules for developing meaning and theory directly from the data itself (e.g., interview transcripts or participant observation field notes) inductively. This is achieved through the iterative process of applying codes to isolated segments of text, analytical memoing, and then constantly comparing these across cases to develop and link higher order concepts and categories (Corbin and Strauss 2008). GT has evolved into separate camps over the years, representing fundamentally different ways of approaching text analysis. We employ a modified GT approach that stems from the "constructivist approach," which applies the same general principles of GT in a flexible way, but also acknowledges that the researcher's positions and previous knowledge base affect the ways in which data are interpreted (Charmaz 2006, 2011). Additionally, real-world problems are complex, and are situated within broader socio-cultural, political, economic, and environmental considerations. Therefore, a modified GT aims to understand and analyze data through an iterative process, whereby codes, concepts, and categories can "emerge" from the data as in the traditional GT approach, but can also be situated within the context of relevant literature (Corbin and Strauss 2008, Bryant and Charmaz 2010). For example, we developed the interview protocol and framed our analysis using concepts from the resilience and socio-cultural perspectives of energy development literatures (e.g., Adger 2000, Folke et al. 2010, Becker et al. 2011, Hitchner et al. 2014). However, we derived concept- and place-specific codes from the key informants themselves.

Analysis was carried out using Atlas.ti, a computer-assisted qualitative data analysis software program (http://atlasti.com/), which provided a platform to code, memo, and compare across cases and concepts consistent with GT. The steps used in the analytical process were consistent to that which is described in Corbin and Strauss (2008) and Charmaz (2011). First, each of the transcripts was read in its entirety. Second, the transcripts were read another time and marginal notes were used to record initial thoughts and reflections of the dataset. Third, line-by-line coding was conducted on several of the transcripts to get a deeper understanding of the material from the informants themselves. Fourth, the final codebook was created using an iterative process of open and axial coding, during which memos were used to develop higher order concepts and to link them across concepts and cases. Fifth, analytical functions in Atlas.ti were used to better understand how codes and concepts were shared across our informants (code groundedness), in which ways and under what contexts concepts and codes were discussed in the same segments of text (code co-occurrence and complex code queries), and to what extent these codes were connected to each other and to larger concepts and themes (network analyses). For instance, these functions were used to characterize the following: (a) the social, economic, and ecological opportunities and constraints of WBB; (b) historical path dependencies that affect options for WBB development now and into the future; and (c) the multiple, and at times conflicting, objectives and perspectives that affect WBB in local contexts. Finally, findings from the text analysis were supplemented with document analysis of relevant literature from the case site, including peer-reviewed and grey literature on socioeconomic and land-use trends, forest condition, and forest management, and of local news stories on WBB development in the area.

\section{RESULTS}

Findings are organized in four thematic sections. The first three sections highlight the economic, social, and ecological opportunities and constraints of WBB in turn (See Appendix 2 for a network analysis of the relationships between major codes, concepts, and themes that provided structure to the analysis herein). This ordering allows for rich description of multiple perspectives and contradictions among stakeholders. Finally, local historical impacts of WBB and logging operations are presented to highlight many of the constraints identified in the interviews.

Analyses focus on the historical path dependencies that shape current conditions and options for change, and the multiple, conflicting objectives, values, and practices surrounding natural resource management. In doing so, this analysis highlights both external (e.g., economics, policy) and internal (e.g., land tenure change, forest management practices, social context) factors that were addressed by the key informants. Issues that are shared among stakeholder groups (e.g., those codes and concepts with 
Table 2. Economic opportunities and constraints of wood-based bioenergy (WBB) in western Montana. For each root code and subcode, we include the number of times the code was referred to in the interviews (groundedness), the number of key informants that discussed the code, and the percentage of key informants that described the code.

\begin{tabular}{|c|c|c|c|c|}
\hline Concept & Code name & Groundedness $^{\dagger}$ & $\begin{array}{l}\text { Number of key } \\
\text { informants }\end{array}$ & $\begin{array}{c}\% \text { Key } \\
\text { informants }\end{array}$ \\
\hline \multirow[t]{5}{*}{ Economic opportunities } & Utilization of small, nonmerch material ${ }^{*}$ & 18 & 11 & $65 \%$ \\
\hline & Abundant resource ${ }^{\ddagger}$ & 13 & 9 & $53 \%$ \\
\hline & Local job creation ${ }^{+}$ & 11 & 9 & $53 \%$ \\
\hline & New market for forest material ${ }^{*}$ & 7 & 6 & $35 \%$ \\
\hline & Income potential for land managers ${ }^{*}$ & 6 & 5 & $29 \%$ \\
\hline \multirow[t]{5}{*}{ Economic constraints } & Market competition/integration & 42 & 15 & $88 \%$ \\
\hline & Cost prohibitive & 28 & 14 & $82 \%$ \\
\hline & Non-renewable energy prices & 24 & 14 & $82 \%$ \\
\hline & Capital investment & 12 & 8 & $47 \%$ \\
\hline & Transportation costs & 9 & 8 & $47 \%$ \\
\hline
\end{tabular}

Groundedness refers to the number of times a code occurs in interviews.

Root code: refers to a higher order code. In some cases the root code will have several subcodes that are a part of the root code (See Fig. A2.1).

high groundedness, or discussed among several key informants), as well as diverse perspectives and contradictions are presented. The results that follow are primarily informed by exemplar quotes from the informants whom we interviewed.

\section{Economic opportunities and constraints of WBB}

Key informants described the ways in which past logging operations and fire suppression has contributed to the current condition and composition of forests in this region. Currently, these stands are largely characterized by dense, homogenous age structure stands that are small in diameter and are not suitable as commercial sawlogs. Additionally, the recent mountain pine beetle epidemic has also affected the market viability of "blue stain" timber as described by one private landowner, "Them blue timber isn't worth as much as the good green...they sure dock you for it going into the mills." Without an economic incentive to remove the material, commercial logging operators and private land owners alike chip and scatter, or burn the material on-site.

Therefore, it is not surprising that a large proportion of the stakeholders interviewed described the ability to utilize this small, nonmerchantable material that is abundant across western Montana as a primary opportunity for WBB (Table 2). Many of the informants $(35 \%)$ discussed the utility of developing a market for this material, which may provide an important tool to offset treatment costs for restoration projects on public lands, a potentially important income source for private landowners, and as a mechanism to support local job opportunities for loggers and other forest products workers in an existing, but diminished local industry (Table 2).

However, a majority of the informants acknowledged several economic barriers to WBB, specifically the extent to which WBB could compete with, or be integrated in, current markets $(88 \%)$, and the costs associated with developing WBB industries and technologies are currently prohibitive (82\%; Table 2). For instance, the high cost of energy derived from biomass, relative to low oil and gas prices, was one of the highest cited constraints, and was partly responsible for the stalled development of a CHP facility at a local saw mill (Public forest manager, personal communication). Additionally, several informants cited the capital costs associated with initial investments as potential constraints, and were concerned that WBB would not be feasible absent government subsidies. Finally, the transportation costs associated with hauling the material was an additional concern according to roughly half of the informants (Table 2), which is illustrated here by a forest products professional employed at a local sawmill: "when you talk about non-sawlog material that wouldn't fit as a pulp $\log . . .[w]$ hen you stack them all up, there's a lot of air in there, so any transportation is costly because you're not hauling very much."

\section{Social opportunities and constraints of WBB}

As mentioned above, some informants described local job creation as a direct opportunity for economic development. However, several informants $(35 \%)$ also described the ways in which WBB could indirectly support rural community development (Table 3), especially with regard to maintaining a sense of rural community and social values. This is exemplified by a local rancher and private timberland owner in the Blackfoot valley: "Our communities... really suffer right now for lack of families. Socially that's a big issue for us as our ranches have gotten bigger. It takes fewer people to manage the land. The same with the timber industry. They [are] very mechanized and they don't need the bodies that they used to. Consequently our rural communities have shrunk. It's families that we need to keep them vibrant. Keep kids in school and a sense of community in the communities...The resources are surrounding these small communities so ideally that could be a little bit of boost or growth for our communities as far as families."

Several informants also emphasized the importance of WBB as a mechanism to contribute to the country's renewable energy portfolio and decrease fossil fuel dependence $(41 \%$ and $18 \%$, respectively; Table 3). Yet, informants emphasized the importance of developing local WBB pathways for rural development, and therefore the extent to which WBB development in this area might significantly contribute to a renewable energy economy might be less than in areas where centralized and integrated systems are championed. Although there was some discussion among stakeholders of more centralized market integration (e.g., biochar soil amendments, international pellet markets, and transportation fuels), these were discussed primarily in the context of providing 
Table 3. Social opportunities and constraints of wood-based bioenergy (WBB) in western Montana. For each root code and subcode, we include the number of times the code was referred to in the interviews (groundedness), the number of key informants that discussed the code, and the percentage of key informants that described the code.

\begin{tabular}{|c|c|c|c|c|}
\hline Concept & Code name & Groundedness $^{\dagger}$ & Number of key informants & $\%$ Key informants \\
\hline \multirow[t]{9}{*}{ Social opportunities } & Decentralized energy system ${ }^{\ddagger}$ & 21 & 11 & $65 \%$ \\
\hline & Locally sourced energy & 12 & 9 & $53 \%$ \\
\hline & Combined heat and power (CHP) & 14 & 7 & $41 \%$ \\
\hline & Renewable energy portfolio & 8 & 7 & $41 \%$ \\
\hline & Heat & 9 & 8 & $47 \%$ \\
\hline & Biofuel & 6 & 6 & $35 \%$ \\
\hline & Electricity & 6 & 6 & $35 \%$ \\
\hline & Rural community development ${ }^{\ddagger}$ & 6 & 6 & $35 \%$ \\
\hline & Decrease fossil fuel dependence & 4 & 3 & $18 \%$ \\
\hline \multirow[t]{7}{*}{ Social constraints } & $\begin{array}{l}\text { Opposition by public/ENGO } \\
\text { groups }\end{array}$ & 17 & 11 & $65 \%$ \\
\hline & Consistent supply & 14 & 8 & $47 \%$ \\
\hline & Historical factors & 13 & 7 & $41 \%$ \\
\hline & UMT biomass burner & 12 & 8 & $47 \%$ \\
\hline & Requires access to USFS land & 7 & 4 & $24 \%$ \\
\hline & $\begin{array}{l}\text { Public trust of forest products/ } \\
\text { logging industry }\end{array}$ & 5 & 3 & $18 \%$ \\
\hline & Access in woods & 2 & 2 & $12 \%$ \\
\hline
\end{tabular}

Groundedness refers to the number of times a code occurs in interviews.

"Root code: refers to a higher order code listed under concepts. In some cases the root code will have several subcodes that are part of the root code (See Fig. A2.1)

some of the financial resources to support local, decentralized WBB systems, and mostly under situations in which individuals would benefit locally. Small, decentralized WBB systems were mentioned and supported by a majority of our informants and by all stakeholder groups, at least in some capacity (Table 3 ). Options included locally sourced energy for home-heating; heat, electricity, and/or CHP operations at existing mills; use in schools, as is currently being promoted in the "Fuels for Schools" initiative across Montana; and/or slightly larger operations located in community/government buildings. Also, one community conservation member emphasized that if local biomass was upgraded for use in the transportation fuel industry, the income from producing these fuels should remain as local as possible. The informant referred to creating local jobs using a local resource, and even upgrading the fuels for the premium markets prices in local places rather than shipping off the "raw," less valuable material for upscaling elsewhere (Community conservation member, personal communication).

The reasons for the emphasis on decentralized WBB was due in part to many of the economic constraints discussed above (e.g., transportation costs, capital investment, and oil/gas prices) and the importance of rural economic and community development to informants. Additionally, maintaining a consistent and predictable supply of material in this region is challenging, which was described by several informants (47\%; Table 3). For example, when discussing the scalability of WBB, a forest products professional mentioned, "the predictability of having X number of loads of material, let's say if you had to produce two to four truckloads of material a day...[that] would be incredibly unpredictable. There's many times during the year when, especially in the spring, where our deliveries go to zero. We don't get any truckloads of logs." There are several factors that drive this inconsistency in supply. For instance, the large-scale mortality of the most recent mountain pine beetle epidemic in the region has left in its wake vast amounts of standing dead and/or downed trees, which both limits access to some of these stands and the harvesting equipment is not designed to handle these trees (Forest products professional, personal communication).

Further, the USFS acquired the majority of former Plum Creek land holdings when the corporate timber company began to sell in the mid-to-late 1990s (Belsky 2015). USFS lands have witnessed significant shifts in the values attributed to these forests and the associated primary uses. In particular, USFS lands in this area have transitioned from commodity-based economies focused on timber extraction to recreation-based economics that value biodiversity conservation for threatened and endangered species, such as the grizzly bear.

Additionally, a small, but vocal cohort of environmental groups particularly around Missoula and the Swan Valley oppose harvest treatments on public lands, and have successively litigated timber sale contracts, which has limited the USFS's ability to acquire and carry out harvest treatments (Table 3 ). For example, conservation organizations and environmental groups stalled most logging operations in the early 1990s throughout the Swan Valley until the Swan Valley Grizzly Bear Conservation Agreement was established to ensure bears would not be affected by industry (Community conservation member, personal communication). More recently in 2013, four conservation groups filed a lawsuit challenging logging operations on former Plum Creek lands that had been acquired by the USFS with the attached fiber supply agreement (Forest products professional, personal communication). In 2016, TNC announced that all subsequent logging on these lands were to be terminated (Tabish 2016). This issue is exemplified by a DNRC Service Forester from the region, "Some people that have used to depend on the forest industry when there 
Table 4. Ecological opportunities and constraints of wood-based bioenergy (WBB) in western Montana. For each root code and subcode, we include the number of times the code was referred to in the interviews (groundedness), the number of key informants that discussed the code, and the percentage of key informants that described the code.

\begin{tabular}{|c|c|c|c|c|}
\hline Concept & Code name & Groundedness $^{\dagger}$ & Number of key informants & $\begin{array}{c}\% \text { Key } \\
\text { informants }\end{array}$ \\
\hline \multirow[t]{6}{*}{ Ecological opportunities } & Restore and manage forests & 18 & 11 & $65 \%$ \\
\hline & Climate change mitigation ${ }^{\ddagger}$ & 9 & 7 & $41 \%$ \\
\hline & Reduce fire risks & 5 & 5 & $29 \%$ \\
\hline & Reduce pollution & 4 & 4 & $24 \%$ \\
\hline & Enhance productvitity and biomass & 3 & 3 & $18 \%$ \\
\hline & Carbon sequestration & 3 & 3 & $18 \%$ \\
\hline \multirow[t]{5}{*}{ Ecological constraints } & Nonsustainable harvest ${ }^{*}$ & 11 & 7 & $41 \%$ \\
\hline & $\begin{array}{l}\text { Impacts to forest ecosystem } \\
\text { processes }\end{array}$ & 9 & 6 & $35 \%$ \\
\hline & Climate change mitigation concerns & 9 & 6 & $35 \%$ \\
\hline & Concerns about pollution & 8 & 6 & $35 \%$ \\
\hline & Concerns about carbon neutrality & 4 & 3 & $18 \%$ \\
\hline
\end{tabular}

Groundedness refers to the number of times a code occurs in interviews.

"Root code: refers to a higher order code listed under concepts. In some cases the root code will have several subcodes that are a part of the root code (See Fig. A2.1).

was more mills open and when Plum Creek had the land here, that was logged intensively for forest products. Now all that land is back in the forest service. That's more recreational land and the forest service goes through the law suits before they get the next timber sale out and then they take 5 to 8 years for a timber sale when Plum Creek was cutting 80 million board foot per year."

Therefore, as a result of these historical land tenure and land use changes, and the socio-political climate of the region, maintaining a consistent timber supply is unpredictable. As a result, the amount of timber harvested on public lands has witnessed a steady decline in recent decades, which in turn has impacted local mill operators, loggers, and private landowners. It is important to note that several of the informants $(25 \%)$ emphasized that the USFS would have to be capable of supplying material to support a sustainable WBB industry (Table 3). However, this may not be feasible given the different perspectives among groups.

\section{Ecological opportunities and constraints of WBB}

A large proportion of informants focused on ecological opportunities, for example the opportunity for WBB to restore forests $(65 \%$; Table 4$)$, primarily with regard to reducing risks from wildfire, and enhancing the productivity of stands to promote forest health. However, two counternarratives were described. First, a key informant from a local ENGO group emphasized that the "forest health crisis" narrative, which suggests forests are unhealthy and therefore thinning treatments are required to restore forest health and resiliency, is not supported by the best available science, and has been used by industry and agency entities to secure forest harvesting and fuels reduction treatments into the future. Second, several informants (35\%; Table 4) mentioned concerns regarding the potential negative environmental impacts of removing biomass from sites (e.g., disruption of soil nutrient cycles, reduction of microbial activity, reduction of tree growth, etc.), which are well documented (e.g., Caputo et al. 2016, Scott and Page-Dumroese 2016). It is not to say that those who described this second narrative were opposed to thinning treatments or did not agree that thinning for WBB could support forest health and restoration, but that these potential activities and impacts be cautiously considered and documented.

Additionally, many of the informants and stakeholder groups agreed that WBB could help to mitigate climate change $(41 \%$; Table 4). This could be achieved by sequestering carbon vis-à-vis bio-char amendments, and reducing pollution, which was described primarily in the context of reducing smoke from wildfire and/or prescribed burns of material that is otherwise left on site. However, several of the informants voiced concerns about the ability of WBB to mitigate the impacts of anthropogenic climate change. These concerns ranged from how WBB would affect air quality and air pollution (35\%), and the extent to which these systems are indeed carbon neutral (18\%; Table 4). In this context, informants explained how biomass boilers are not "clean" and might still produce a significant amount of smoke. They also questioned the state of the technology and science behind carbon accounting studies, such as life-cycle assessments.

Situating the opportunities and constraints of WBB in historical context: The University of Montana biomass boiler and logging operations

Many of the constraints of WBB posed by our informants can be illustrated through the lens of two historical events that were consistently described during interviews, and which affected the considerations of WBB. The University of Montana (UMT) in Missoula proposed a US\$16 million on-campus biomass burning facility, which intended to use approximately 16 thousand bone dry tons (bdt) per year of biomass from commercial slash-logging residues and other small diameter $(<18 \mathrm{~cm})$ trees recovered from both public (e.g., Lolo and Bitteroot National Forests, BLM, and DNRC) and private lands surrounding the Missoula area (DNRC 2011). Because the project was being proposed on a state university campus and required access to biomass from public lands, the project was open to comment and received a significant amount of press (One reporter specifically, Chelsi Moi from the Missoulan, covered this story extensively from 2010-2011). Questions were raised from the public and ENGO groups regarding many of the constraints described by our informants, 
including concerns about air quality and pollution in Missoula (Table 4). This stemmed from the propensity of severe wintertime air inversions in the Missoula valley, and many local residents were displeased that a wood-burning facility was proposed in the city limits despite the fact that city ordinances forced thousands of community members to stop using home-heating wood stoves (Moy 2011a). Three local ENGO groups, including the Alliance for the Wild Rockies, Friends of the Wild Swan, and the Montana Ecosystems Defense Council, opposed the project from the beginning and officially appealed the air quality permit, citing that the study had failed to account for cumulative effects of the biomass boiler on air pollution, and suggested that the project would further contribute to climate change, not mitigate the effects of climate change (Moy 2011b).

In a similar vein, local residents called into question the scientific credibility of the feasibility study that was conducted for the plant, while the UMT biomass heating system supervisor suggested facts were put aside to push the project forward (Moy 2011c). For instance, local residents and the executive director of a local ENGO group suggested that the project feasibility study overinflated the projected cost of natural gas, and underestimated the cost of transporting material from the forest to the university (Koehler et al. 2011). This may be, in part, the reason for which UMT officials had a tough time securing a timber supplier that could provide the material at a low cost (Moy 2011a). A local logger from the area did suggest that UMT officials associated with the biomass boiler project were attempting to price fix contract bids for logging operations. In the end, the UMT biomass plant was eventually scrapped all together, as even the biomass plant engineers at UMT openly opposed the plant because of the factors mentioned above, and specifically the inability to compete with current and projected oil and natural gas prices (e.g., Moy 2011c), which was the most highly cited economic constraint across our sample (Table 2).

Second, a large proportion of the informants voiced their concerns that emerging WBB industries would harvest material in a nonsustainable manner, similar to the perspectives of some individuals regarding past logging operations in the area that, in essence, liquidated much of the timber resources (Table 3). These logging operations undermined the trust of the public and ENGO groups, which as one informant from a local conservation organization mentioned, "we've been paying the consequences of that for the last 30 years, 40 year[s]" (Community conservation member, personal communication). These concerns were voiced not only by conservation and ENGO groups, but also from some logging professionals who depend on the forests for their livelihoods. For instance, a logger from the Swan Valley voiced his concerns, "My biggest concern would be overdoing it, and getting everything shut down again. We're already having a hard time getting timber removed. I think they're [ENGO groups] just waiting for somebody to pull that plug so they can jump on that and use that for their advantage to stop more work in the forests." Therefore, it is important to consider both the conditions under which previous WBB projects failed, and to ensure any harvest treatments are sustainable to retain not only the public's trust of forest management practices, but also to ensure buy-in from local loggers and other forest products professionals.

\section{DISCUSSION}

The opportunities and constraints of WBB described by key informants in this study align with recent reviews of the diverse perspectives of WBB across the United States and Europe. For instance, Becker et al. (2011) assessed the social dynamics underlying "conventional wisdoms" of WBB across 10 sites in the United States (including the Bitterroot Valley in Montana) using in-depth interviews with industry, agency, community, and tribal representatives. The authors found that consistent supply, especially on federal lands, transportation costs, and the market value and competition of biomass and WBB with alternative fuels hindered biomass use. Further, Hitchner et al. (2014) employed a strengths, weaknesses, opportunities, and threats (SWOT) framework to summarize key themes in the literature (e.g., peerreviewed, grey literature, and news articles) regarding public opinion of WBB in the United States and Europe. These authors found that many of the strengths/opportunities of WBB were local energy production and decentralized energy systems, and new markets and income sources for land managers, among others. Conversely, many of the weaknesses and threats identified included concerns about negative impacts to forests, the sustainability of WBB, and how past WBB failures affect public opinion (Hitchner et al. 2014).

Therefore, this study adds to existing empirical work on the opportunities and constraints of WBB across forest-dependent communities in the United States. We provide additional insights of the context-specific factors that enable or constrain WBB, and under what conditions WBB can contribute to forest and community resilience in this particular area of western Montana. First, the results of this study illustrate how path dependent trajectories of change create "lock-in" effects that, when coupled with an understanding of diverse values and the socio-cultural and political context, can affect the capacity to implement WBB (Smit and Wandel 2006, Nelson et al. 2007, Beier et al. 2009, Cote and Nightingale 2011, Armitage et al. 2012, Scott 2013). Key informants described WBB as an opportunity to create alternative markets for dead and overstocked stands, support rural community development, and as a way to restore forests. However, the ability to do so is constrained by exorbitant haul costs, capital investment requirements, and consistently low oil and gas prices. Additionally, the area has witnessed significant changes to land tenure over the course of the last few decades, specifically the selling of Plum Creek land to the USFS. Concomitantly, the USFS has witnessed shifts in values concerning land uses here and elsewhere, from commodity-based extraction industries to recreation-based economies and conservation-oriented objectives, which has reduced the capacity of the USFS to harvest timber. Furthermore, the concentration of ENGO groups in the area, who hold different values regarding use of forests on public land, has led to heightened scrutiny of proposed harvest treatments and further reduced harvesting capacity on these lands in recent years. Environmental policies (e.g., NEPA and ESA) enable these groups to challenge forest management practices and in effect have a political advantage to control the ways in which forests are managed and used (Charnley et al. 2008, Cote and Nightingale 2011). The USFS is the majority landowner in the region, and therefore the unpredictability and inconsistency in the supply chain affects the entire industry, including private landowners, 
which in turn also affects the scope and scale of WBB industries that are possible in the region.

Second, these results highlight multiple perspectives, contradictions, and trade-offs of WBB in this area of western Montana, and by doing so provides a step toward identifying the most desirable and plausible development pathway that also supports forest and community resilience (Nelson et al. 2007, Crane 2010, Armitage et al. 2012). For instance, given the diverse framings that exist on how public lands should be used, development in this area is most likely to be successful if not proposed on public lands, or at very minimal harvest levels. Further, a set of historical factors have affected the ways that different groups frame WBB. Although many informants described WBB as an opportunity for climate change mitigation, others questioned the extent to which emerging WBB systems are indeed carbon neutral, and is reflected in understandings of previous technologies and debates that ultimately shut down the University of Montana biomass boiler. Also, although many informants suggested that WBB could reduce wildfire risks and enhance forest health and resilience, others suggested that the "forest health crisis" narrative is the product of vested agency and business interests. Therefore, it is important to consider these when introducing WBB projects, particularly with respect to providing the best available science when developing life-cycle assessments and cost accounting measurements, and ensuring careful consideration of how discourses are framed and contested.

Finally, most individuals and all stakeholder groups supported local and decentralized WBB systems, such as CHP at local sawmills, or heating and/or electricity for schools and other community buildings. The support for small, decentralized systems in part reflects many of the opportunities and constraints identified, such as transportation costs, predictability of raw materials, history, potential negative environmental impacts, the desire to support local rural community development, etc. Also, using WBB for schools and other buildings are already in operation in Montana, such as the "Fuels for School" initiative. Although low oil and gas prices have diluted the overarching success of these initiatives at times, many of these systems use established technologies that have tangible results; are retro-fitted to utilize wood chips and/or natural gas given market prices and conditions, which provides flexibility; have supported local jobs; have reduced fuel and/or heating costs; and have helped pay for restoration work. Further, existing mills already deal with a significant amount of residues. A locally stationed operation next to existing sawmills would provide an outlet for the residual biomass and could further support an existing, but diminished forest products sector in this area of western Montana.

The resilience of SESs, and the options considered to deal with change are embedded in current and historical socio-cultural, economic, political, and environmental contexts. As with any development project, there are a multitude of trade-offs and perspectives that reflect individual and community/group experiences and values associated with natural resources in local places. As we illustrate in this case, these factors can enable or constrain adaptation options, and must be considered when determining of what, to what, and for whom resilience is sought (Carpenter et al. 2001, Lebel et al. 2006). It is important that any
WBB development in this area consider these lessons learned to develop a more sustainable bioenergy pathway that contributes to resilient forests and communities under change.

\section{CONCLUSIONS}

It has been argued that utilizing forest residues for WBB presents an opportunity to mitigate the impacts of climate change, reduce vulnerability to future disturbance, and ultimately promote resilience in forest and social systems. However, the ways in which emerging WBB systems will impact SESs are highly varied because of the multitude of feedstock sources, pathways, scales, and end uses. The feasibility of WBB in local places is contingent upon local social and ecological contexts, which too are embedded in, and impacted by, national- and global-level drivers, such as market prices and competition among energy options, and the changing face and locale of forest products markets and economies, among others.

This exploratory case study was conducted in rural, forestdependent communities in western Montana, and was informed by in-depth interviews with key informants who have been involved with forest management issues for many years. We provided information to better understand the opportunities and constraints associated with WBB in local social and ecological contexts, and to document under what contexts WBB could promote forest and community resilience. Results illustrate that WBB development is embedded in the historical and contemporary social, economic, and ecological contexts of particular places. Local values and perspectives are complex and dynamic, reflecting multiple, and at times, competing perspectives and objectives regarding forest management practices in general and WBB development in particular. Considering the role of these context-specific and path-dependent factors, while also considering the role of national and global-level drivers in shaping local options, is imperative to determine socially and culturally appropriate and sensitive development pathways that contribute to social and ecological resilience.

The results of this study provide a set of key insights, multiple perspectives, and contradictions of WBB development in western Montana, and our results align with recent reviews of stakeholder perceptions of $\mathrm{WBB}$, including those of the broader public (Becker et al. 2011, Hitchner et al. 2014). As such, these findings provide a starting point to identify the opportunities and constraints of WBB development in this area. Yet, in order to more fully understand the context-specific factors that enable, and/or create resistance to, WBB development, additional research with community members who are not involved in, and perhaps are not as knowledgeable about forest management and biomass use should be considered as a next step because they too will ultimately influence the scope and scale of WBB development. Additional next steps for this research will be to expand, link, and compare this exploratory case study within and between stakeholder groups, rural communities, watersheds, and regions from ongoing studies throughout Montana, Colorado, Wyoming, and Idaho.

Responses to this article can be read online at: http://www.ecologyandsociety.org/issues/responses. php/9157 


\section{Acknowledgments:}

We would like to thank all the individuals who volunteered to participate in this study, in addition to the University of Montana Extension Forestry staff, especially Peter Kolb and Martin Twer, for their assistance identifying participants. This project was carried out under the Bioenergy Alliance Network of the Rockies (BANR; http://banr.nrel.colostate.edul) and was supported by an Agriculture and Food Research Initiative Competitive Grant (\#2013-68005-21298) from the USDA National Institute of Food and Agriculture.

\section{LITERATURE CITED}

Adger, W. N. 2000. Social and ecological resilience: are they related? Progress in Human Geography 24:347-364. http://dx.doi. org/10.1191/030913200701540465

Allen, C. D., A. K. Macalady, H. Chenchouni, D. Bachelet, N. McDowell, M. Vennetier, T. Kitzberger, A. Rigling, D. D. Breshears, E. H. Hogg, P. Gonzalez, R. Fensham, Z. Zhang, J. Castro, N. Demidova, J.-H. Lim, G. Allard, S. W. Running, A. Semerci, and N. Cobb. 2010. A global overview of drought and heat-induced tree mortality reveals emerging climate change risks for forests. Forest Ecology and Management 259:660-684. http:// dx.doi.org/10.1016/j.foreco.2009.09.001

Armitage, D., C. Béné, A. T. Charles, D. Johnson, and E. H. Allison. 2012. The interplay of well-being and resilience in applying a social-ecological perspective. Ecology and Society 17 (4):15. http://dx.doi.org/10.5751/es-04940-170415

Baginski, J., and C. Biermann. 2010. Montana on the fly: a state hooked on trout. FOCUS on Geography 53:142-147. http://dx.doi. org/10.1111/j.1949-8535.2010.00017.X

Becker, D. R., D. Abbas, K. E. Halvorsen, P. Jakes, S. M. McCaffrey, and C. Moseley. 2011. Conventional Wisdoms of woody biomass utilization. Journal of Forestry 109:208-218.

Beier, C. M., A. L. Lovecraft, and F. S. Chapin. 2009. Growth and collapse of a resource system: an adaptive cycle of change in public lands governance and forest management in Alaska. Ecology and Society 14(2):5. http://dx.doi.org/10.5751/es-02955-140205

Belsky, J. M. 2015. Community forestry engagement with market forces: a comparative perspective from Bhutan and Montana. Forest Policy and Economics 58:29-36. http://dx.doi.org/10.1016/ j.forpol.2014.11.004

Bentz, B. J., J. Régnière, C. Fettig, E. M. Hansen, J. L. Hayes, J. A. Hicke, R. G. Kelsey, J. F. Negrón, and S. J. Seybold. 2010. Climate change and bark beetles of the western United States and Canada: direct and indirect effects. Bioscience 60:602-613. http:// dx.doi.org/10.1525/bio.2010.60.8.6

Berkes, F., J. Colding, and C. Folke, editors. 2003. Navigating social-ecological systems: building resilience for complexity and change. Cambridge University Press, Cambridge, UK. http://dx. doi.org/10.1017/cbo9780511541957

Bernard, H. R. 2006. Research methods in anthropology: qualitative and quantitative approaches. Fourth edition. Atla Mira, Landham, Maryland, USA.
Bliss, J. C., E. C. Kelly, J. Abrams, C. Bailey, and J. Dyer. 2010. Disintegration of the U.S. industrial forest estate: dynamics, trajectories, and questions. Small-scale Forestry 9:53-66. http:// dx.doi.org/10.1007/s11842-009-9101-7

Brown, K. 2014. Global environmental change I: a social turn for resilience? Progress in Human Geography 38:107-117. http://dx. doi.org/10.1177/0309132513498837

Bryant, A., and K. Charmaz. 2010. The SAGE handbook of grounded theory. SAGE, London, UK.

Caputo, J., C. M. Beier, P. M. Groffman, D. A. Burns, F. D. Beall, P. W. Hazlett, and T. E. Yorks. 2016. Effects of harvesting forest biomass on water and climate regulation services: a synthesis of long-term ecosystem experiments in eastern North America. Ecosystems 19:271-283. http://dx.doi.org/10.1007/s10021-015-9928$\underline{Z}$

Carpenter, S., B. Walker, J. M. Anderies, and N. Abel. 2001. From metaphor to measurement: resilience of what to what? Ecosystems 4:765-781. http://dx.doi.org/10.1007/s10021-001-0045-9

Cestero, B., and J. M. Belsky. 2003. Collaboration for community and forest well-being in the Upper Swan Valley, Montana. Pages 149-169 in J. Kusel and E. Adler, editors. Forest communities, community forests. Rowman and Littlefield, Oxford, UK.

Charmaz, K. 2006. Constructing grounded theory: a practical guide through qualitative research. SAGE, London, UK.

Charmaz, K. 2011. A constructivist grounded theory analysis of losing and regaining a valued self. Pages 165-204 in F. J. Wertz, K. Charmaz, L. M. McMullen, R. Josselson, R. Anderson, and E. McSpadden, editors. Five ways of doing qualitative analysis: phenomenological psychology, grounded theory, discourse analysis, narrative research, and intuitive inquiry. Guilford, New York, New York, USA.

Charnley, S., R. J. Mclain, and E. M. Donoghue. 2008. Forest management policy, amenity migration, and community wellbeing in the American West: reflections from the northwest forest plan. Human Ecology 36:743-761. http://dx.doi.org/10.1007/ s10745-008-9192-3

Corbin, J., and A. Strauss. 2008. Basics of qualitative research: techniques and procedures for developing grounded theory. SAGE, London, UK. http://dx.doi.org/10.4135/9781452230153

Cote, M., and A. J. Nightingale. 2011. Resilience thinking meets social theory: situating social change in socio-ecological systems (SES) research. Progress in Human Geography 36:475-489. http:// dx.doi.org/10.1177/0309132511425708

Crane, T. A. 2010. Of models and meanings: cultural resilience in social-ecological systems. Ecology and Society 15(4):19. http:// dx.doi.org/10.5751/ES-03683-150419

Dale, B. E., J. E. Anderson, R. C. Brown, S. Csonka, V. H. Dale, G. Herwick, R. D. Jackson, N. Jordan, S. Kaffka, K. L. Kline, L. R. Lynd, C. Malmstrom, R. G. Ong, T. L. Richard, C. Taylor, and M. Q. Wang. 2014. Take a closer look: biofuels can support environmental, economic and social goals. Environmental Science and Technology 48:7200-7203. http://dx.doi.org/10.1021/es5025433

Dennison, P. E., S. C. Brewer, J. D. Arnold, and M. A. Moritz. 2014. Large wildfire trends in the western United States, 
1984-2011. Geophysical Research Letters 41:2928-2933. http://dx. doi.org/10.1002/2014GL059576

Department of Natural Resources and Conservation (DNRC). 2011. Supply assessment of forest logging residues and nonsawlog biomass in the vicinity of Missoula, Montana, 2011-2013. Prepared by the Montana Department of Natural Resources and Conservation Biomass Utilization Program for the University of Montana, Missoula, USA. [online] URL: http://studylib.net/ doc/11895708/supply-assessment-of-forest-logging-residues-andnon-sawlog

Department of Natural Resources and Conservation (DNRC). 2014. Montana forest health highlights 2014. Forest pest management program, Montana Department of Natural Resources and Conservation, Helena, Montana, USA. [online] URL: http://dnrc.mt.gov/divisions/forestry/docs/assistance/pests/ conditions-highlights/fhh-2014.pdf

Díaz, S., S. Demissew, J. Carabias, C. Joly, M. Lonsdale, N. Ash, A. Larigauderie, J. R. Adhikari, S. Arico, A. Báldi, et al. 2015. The IPBES Conceptual Framework - connecting nature and people. Current Opinion in Environmental Sustainability 14:1-16. http://dx.doi.org/10.1016/j.cosust.2014.11.002

Donoghue, E. M., and V. E. Sturtevant. 2008. Forest community connections: implications for research, management, and governance. Resources for the Future, Washington, D.C., USA.

Eckhoff, M., and K. Mackes. 2010. A case for increasing forest biomass utilization research in Colorado. Western Journal of Applied Forestry 25:22-26.

Farr, A. 2011. Fuels for schools goes to college. U.S. Forest Service, Missoula, Montana, USA. [online] URL: http://www.fs.usda. gov/Internet/FSE DOCUMENTS/stelprdb5341788.pdf

Fischer, W. C., and A. F. Bradley. 1987. Fire ecology of western Montana forest habitat types. General Technical Report INT-223. U.S. Forest Service, Ogden, Utah, USA.

Folke, C. 2006. Resilience: the emergence of a perspective for social-ecological systems analyses. Global Environmental Change 16:253-267. http://dx.doi.org/10.1016/j.gloenvcha.2006.04.002

Folke, C., S. R. Carpenter, B. Walker, M. Scheffer, T. Chapin, and J. Rockström. 2010. Resilience thinking: integrating resilience, adaptability and transformability. Ecology and Society 15(4):20. http://dx.doi.org/10.5751/es-03610-150420

Glaser, B., and A. Strauss. 1967. The discovery grounded theory: strategies for qualitative inquiry. Weidenfeld and Nicholson, London, UK.

Gunderson, L. H., and C. S. Holling. 2002. Panarchy: understanding transformations in systems of humans and nature. Island, Washington, D.C., USA.

Haugo, R. D., S. A. Hall, E. M. Gray, P. Gonzalez, and J. D. Bakker. 2010. Influences of climate, fire, grazing, and logging on woody species composition along an elevation gradient in the eastern Cascades, Washington. Forest Ecology and Management 260:2204-2213. http://dx.doi.org/10.1016/j.foreco.2010.09.021

Hitchner, S., J. Schelhas, T. Hujala, and J. P. Brosius. 2014. Public opinion and wood energy. Pages 32-74 in F. X. Aguilar. Wood energy in developed economies: resource management, economics and policy. Routledge, New York, New York, USA.

Hodbod, J., and W. N. Adger. 2014. Integrating social-ecological dynamics and resilience into energy systems research. Energy Research and Social Science 1:226-231. http://dx.doi.org/10.1016/ j.erss.2014.03.001

Hoekman, S. K. 2009. Biofuels in the U.S.-challenges and opportunities. Renewable Energy 34:14-22. http://dx.doi. org/10.1016/j.renene.2008.04.030

Jones, G., D. Loeffler, E. Butler, S. Hummel, and W. Chung. 2013. The financial feasibility of delivering forest treatment residues to bioenergy facilities over a range of diesel fuel and delivered biomass prices. Biomass and Bioenergy 48:171-180. http://dx.doi. org/10.1016/j.biombioe.2012.11.023

Keane, R. E., and S. F. Arno. 1993. Rapid decline of whitebark pine in western Montana: evidence from 20-year remeasurements. Western Journal of Applied Forestry 8:44-47.

Koehler, M., I. M. Lange, and J. Snively. 2011. Questions about University of Montana's biomass plans. NewWest, 12 May. [online] URL: http://newwest.net/topic/article/questions aboutuniversity of montanas biomass plans/C37/L37/

Lebel, L., J. M. Anderies, B. Campbell, C. Folke, S. HatfieldDodds, T. P. Hughes, and J. Wilson. 2006. Governance and the capacity to manage resilience in regional social-ecological systems. Ecology and Society 11(1):19. http://dx.doi.org/10.5751/ es-01606-110119

Lovio, R., P. Mickwitz, and E. Heiskanen. 2011. Path dependence, path creation and creative destruction in the evolution of energy systems. Pages 274-301 in R. Wüstenhagen and R. Wuebker, editors. Handbook of research on energy entrepreneurship. Edward Elger, Cheltenham, UK. http://dx.doi.org/10.4337/9780857931221.00024

Lydersen, J. M., M. P. North, E. E. Knapp, and B. M. Collins. 2013. Quantifying spatial patterns of tree groups and gaps in mixed-conifer forests: reference conditions and long-term changes following fire suppression and logging. Forest Ecology and Management 304:370-382. http://dx.doi.org/10.1016/j. $\underline{\text { foreco.2013.05.023 }}$

Marschke, M. J., and F. Berkes. 2006. Exploring strategies that build livelihood resilience: a case from Cambodia. Ecology and Society 11(1):42. http://dx.doi.org/10.5751/es-01730-110142

Mehl, C., J. Haufler, S. Yeats, and B. Rieman. 2012. Southwestern crown of the continent landscape assessment. Challenge Cost Share Agreement \#11-CS-11011600-03, U.S. Forest Service and the Ecosystem Management Research Institute. [online] URL: $\underline{\text { http:// }}$ www.swcrown.org/wp-content/uploads/2015/02/SW-Crown-LandscapeAssessment.pdf

Montana Office of Tourism. 2015. Montana Office of Tourism and Montana Film Office annual report 2014-15. Montana Office of Tourism, Helena, Montana, USA. [online] URL: http:// marketmt.com/Portals/129/shared/docs/AnnualReports/annualReport15. pdf

Moy, C. $2011 b .3$ groups appeal air quality permit for UM biomass boiler. Missoulian, 19 July. [online] URL: http://missoulian.com/ news/local/groups-appeal-air-quality-permit-for-um-biomass-boiler/ article a177667c-b1bb-11e0-8354-001cc4c002e0.html 
Moy, C. 2011c. Biomass boiler proposal slammed by University of Montana plant employees. Missoulian, 19 May. [online] URL: http://missoulian.com/news/local/biomass-boiler-proposal-slammedby-university-of-montana-plant-employees/article 58010b6c-81cb-11e0-863d-001cc4c03286.html

Moy, C. 2011a. UM scraps biomass heating plant, apologizes for 'eco-terrorism' remark. Missoulian, 3 December. [online] URL: http://missoulian.com/news/local/um-scraps-biomass-heating-plantapologizes-for-eco-terrorism-remark/article 8862e060-1d29-11e1$\underline{\text { b5f9-0019bb2963f4.html }}$

Murray, R. 2013. Biomass bonanza: Stoltze starts making power with co-generator. Daily Inter Lake, 25 October. [online] URL: http://www.dailyinterlake.com/members/biomass-bonanza-stoltzestarts-making-power-with-co-generator/article 49425496-3dcb-11e3b36a-0019bb2963f4.html

Nelson, D. R., W. N. Adger, and K. Brown. 2007. Adaptation to environmental change: contributions of a resilience framework. Annual Review of Environment and Resources 32:395-419. http:// dx.doi.org/10.1146/annurev.energy.32.051807.090348

North, D. C. 1990. Institutions, institutional change and economic performance. Cambridge University Press, Cambridge, UK. http://dx.doi.org/10.1017/cbo9780511808678

Openshaw, K. 2010. Biomass energy: employment generation and its contribution to poverty alleviation. Biomass and Bioenergy 34:365-378. http://dx.doi.org/10.1016/j.biombioe.2009.11.008

Parker, M. 2014. Swan story. Pages 123-136 in S. Charnley, T. E. Sheridan, and G. P. Nabhan, editors. Stitching the west back together: conservation of working landscapes. University of Chicago Press, Chicago, Illinois, USA. http://dx.doi.org/10.7208/ chicago/9780226165851.003.0009

Patton, M. Q. 2002. Qualitative research and evaluation methods. SAGE, Thousand Oaks, California, USA.

Peterson, C. 2013. Stoltze celebrates co-gen plant. Hungry Horse News, 17 July.

Polagye, B. L., K. T. Hodgson, and P. C. Malte. 2007. An economic analysis of bio-energy options using thinnings from overstocked forests. Biomass and Bioenergy 31:105-125. http://dx.doi. org/10.1016/j.biombioe.2006.02.005

Prato, T., and D. Fagre. 2007. Sustaining Rocky Mountain landscapes: science, policy, and management for the Crown of the Continent ecosystem. Washington, DC,USA: Resources for the Future (RFF).

Richter Jr, D., D. H. Jenkins, J. T. Karakash, J. Knight, L. R. Mccreery, and K. P. Nemestothy. 2009. Resource policy. Wood energy in America. Science 323:1432-1433. http://dx.doi. org/10.1126/science. 1166214

Scott, D. A., and D. S. Page-Dumroese. 2016. Wood bioenergy and soil productivity research. Bioenergy Research 9:507-517. http://dx.doi.org/10.1007/s12155-016-9730-6

Scott, M. 2013. Resilience: a conceptual lens for rural studies? Geography Compass 7:597-610. http://dx.doi.org/10.1111/ gec3.12066
Smit, B., and J. Wandel. 2006. Adaptation, adaptive capacity and vulnerability. Global Environmental Change 16:282-292. http://dx. doi.org/10.1016/j.gloenvcha.2006.03.008

Sovacool, B. K. 2009a. The intermittency of wind, solar, and renewable electricity generators: technical barrier or rhetorical excuse? Utilities Policy 17:288-296. http://dx.doi.org/10.1016/j. jup.2008.07.001

Sovacool, B. K. 2009b. Rejecting renewables: the socio-technical impediments to renewable electricity in the United States. Energy Policy 37:4500-4513. http://dx.doi.org/10.1016/j.enpol.2009.05.073

Strauss, S., and D. Reeser. 2013. Siting, scale, and social capital: wind energy development in Wyoming. Pages 110-125 in $\mathrm{S}$. Strauss, S. Rupp, and T. Love, editors. Cultures of energy: power, practices, technologies. Left Coast Press, Walnut Creek, California, USA.

Tabish, D. 2016. Nature conservancy ends logging on Swan Valley 'Legacy Lands.' Flathead Beacon, 29 February. [online] URL: http://flatheadbeacon.com/2016/02/29/nature-conservancy-endslogging-on-swan-valley-legacy-lands/

Toppinen, A., Y. Zhang, W. Geng, S. Laaksonen-Craig, K. Lähtinen, N. Li, C. Liu, I. Majumdar, and Y. Shen. 2010. Changes in global markets for forest products and timberlands. Pages 137-156 in G. Mery, P. Katila, G. Galloway, R. I. Alfaro, M. Kanninen, M. Lobovikov, and J. Varjo, editors. Forests and society - responding to global drivers of change. International Union of Forest Research Organizations, Vienna, Austria. [online] URL: http://www.iufro.org/download/file/5895/4668/135-156 pdf/

Trosper, R. L. 2003. Policy transformations in the US forest sector, 1970-2000: implications for sustainable use and resilience. Pages 328-351 in F. Berkes, J. Colding, and C. Folke, editors. Navigating social-ecological systems: building resilience for complexity and change. Cambridge University Press, Cambridge, UK.

Unruh, G. C. 2000. Understanding carbon lock-in. Energy Policy 28:817-830. http://dx.doi.org/10.1016/S0301-4215(00)00070-7

Walker, B., C. S. Holling, S. R. Carpenter, and A. Kinzig. 2004. Resilience, adaptability, and transformability in social-ecological systems. Ecology and Society 9(2):5. http://dx.doi.org/10.5751/ es-00650-090205

Weaver, J. L. 2014. Conservation legacy on a flagship forest: wildlife and wildlands on the Flathead National Forest, Montana. Wildlife Conservation Society Working Paper, No. 43. Bronx, New York, USA. [online] URL: http://headwatersmontana.org/sites/default/ files/Weaver Conservation Legacy FNF 2014 Web.pdf

West, J., I. Bailey, and M. Winter. 2010. Renewable energy policy and public perceptions of renewable energy: a cultural theory approach. Energy Policy 38:5739-5748. http://dx.doi.org/10.1016/ j.enpol.2010.05.024

Westley, F., S. R. Carpenter, W. A. Brock, C. S. Holling, and L. H. Gunderson. 2002. Why systems of people and nature are not just social and ecological systems. Pages 103-120 in L. H. Gunderson and C. S. Holling, editors. Panarchy: understanding transformations in human and natural systems. Island, Washington, D.C., USA. 
Ecology and Society 22(2): 9

https://www.ecologyandsociety.org/vol22/iss2/art9/

Westover, R. 2011. USDA Forest Service's fuels for schools program turns biomass into energy. U.S. Department of Agriculture, Washington, D.C., USA. [online] URL: https://www. usda.gov/media/blog/2011/04/12/usda-forest-services-fuels-schoolsprogram-turns-biomass-energy 


\section{Appendix 1: Interview Protocol}

1. Can you please tell me a little about your background, how long you have been here, and what your work/management duties entail?

2. Can you please tell me about the forests here?

a. What are the major ecosystem types/communities?

b. What are the primary fish, wildlife, and water sources in these forests?

c. What are the benefits that forests provide?

d. What do you value about these forests?

3. What are the major uses of these forests? (ie. recreation, commercial products, subsistence, education, aesthetic, others)?

a. Have these uses changed over time, in your experience? In what ways?

4. Can you tell me about the condition of the forests?

5. What, if any, changes have you noticed to the condition of these forests? (Probe: Over what time period/how long?)

6. Are there any particular pests or other natural problems that you think have affected the condition of the forests?

7. Are there any human-caused changes to the forest?

8. How have these changes due to humans, pests or other natural problems impacted the forest and human livelihoods?

9. What measures have been taken to mitigate [alleviate or try to stop] these changes due to humans, pests, or other natural problems and restore forests?

10. What are the barriers or constraints to addressing, responding, or preparing for these changes?

11. Can you please tell me what you know about bioenergy?

12. What are the pros and cons of bioenergy in your opinion? [Probe: environment, renewable resources, economics, health, community development]

13. Have there been any recent efforts to incorporate biofuel/bioenergy development in this area?

a. If so, what were they?

b. Were they successful? Why or why not?

14. Do you think a bioenergy industry would benefit this area?

a. What do you consider are the positive/negative effects?

b. What are the opportunities/constraints (Probe: these could be economic, political, financial, aesthetic, etc)?

c. What would be needed to ensure that bioenergy/biofuels are sustainable and contribute to local needs?

15. How about the use of forest management for bioenergy [For example, using trees that are removed from the forest to reduce wildfire risk to produce bioenergy]?

a. What do you consider are the positive and/or negative effects?

b. What do you consider are the opportunities/constraints?

c. What are some concerns that you have about the use of forests for bioenergy/biofuels?

16. Anything else we haven't discussed that you would like to tell me about?

17. Is there anyone else who you think I should talk to about these topics? 
Appendix 2: Network analysis of the opportunities and constraints of wood-based bioenergy (WBB) in western Montana.

Below, we use a network analysis to illustrate the major concepts and codes derived from interviews, and how they relate to one another (Fig. A2.1). This was created in Atlas.ti, a qualitative software program useful for conducting grounded theory analyses, through an iterative and inductive approach. These concepts and codes are structured around economic, social, and ecological opportunities and constraints

Fig. A2.1. Network analysis of the opportunities and constraints of wood-based bioenergy (WBB) in western Montana. The "opportunities" and "constraints" themes (Pink boxes) are organized around "social", "economic", and "ecological" concepts (Orange boxes). The links between the opportunities and constraints themes and the social, economic, and ecological concepts are denoted with a "is part of" relationship. Several codes and sub-codes (Gray boxes) are attached to each concept. Root codes associated with each concept are linked with a "is $a$ " relationship. Links are also made between root codes and sub-codes with a "is part of" relationship. This iterative and inductive approach resulted in 20 codes associated with the "opportunities" theme, 10 of which were root codes and 10 of which were defined as sub-codes. Alternatively, 17 codes were identified under the "constraints" theme, 8 of which were considered root codes, and 9 were defined as sub-codes.

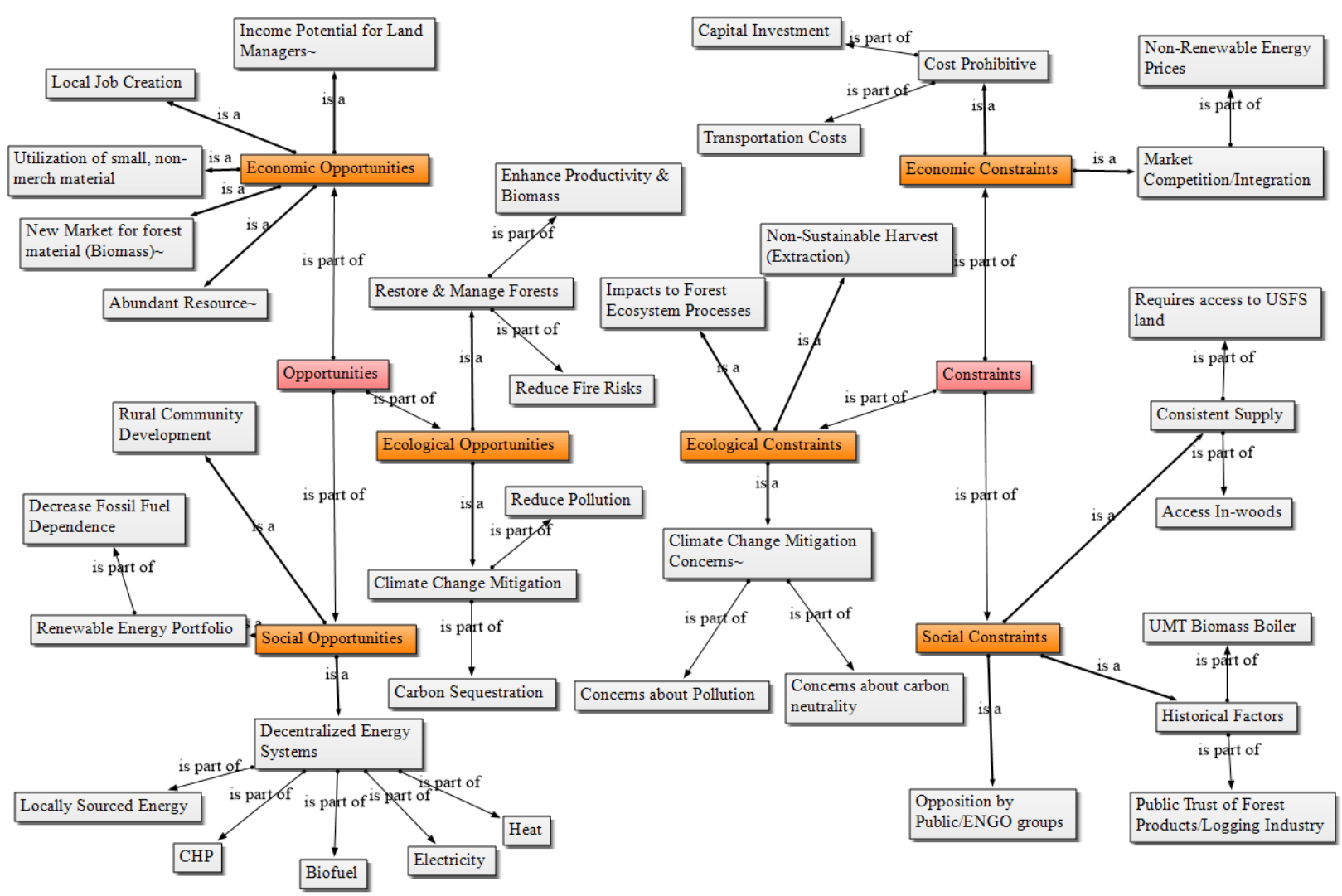

